\title{
Evaluation of dry feeding and liquid feeding to lactating sows under high temperature environment
}

\author{
J. S. Hong, S. S. Jin, S. W. Jung, L. H. Fang and Y. Y. Kim
}

\begin{abstract}
Background: Liquid feeding system has been introduced to domestic swine farms, but negative cognition about liquid feeding system has been remained for feed waste decay related with poor management and microbial contamination. For these reasons, this study was conducted to evaluate the effects of feeding method in lactating sows.

Methods: A total of 30 mixed-parity (average 4.13) lactating sows (Yorkshire $\times$ Landrace) with an initial BW of $218.8 \pm 19$. $5 \mathrm{~kg}$ was used in a 3 week trial. Sows were allotted to 1 of 2 treatments in a completely randomized design by their body weight, backfat thickness, parity and alive litter weight. One of treatments was dry feeding and the other was liquid feeding (water to feed ratio, 1:1). Experimental diets contained $3265 \mathrm{kcal} \mathrm{ME} / \mathrm{kg}, 12.6 \% \mathrm{CP}, 5.76 \% \mathrm{EE}, 1.09 \%$ total lysine, $0.25 \%$ total methionine, as fed basis.

Results: Dry feeding treatment had high body weight loss rather than liquid feeding treatment $(P=0.04)$. Dry feeding treatment had tendency to increase litter weight at $21 \mathrm{~d}$ of lactation $(P=0.06)$ and litter weight gain $(P=0.04)$ during lactation period (0-3 week). Sows fed dry feeding method made milk containing high content of casein and total solid rather than sows fed liquid feeding method $(P=0.04)$. In addition, dry feeding treatment had tendency to higher content of milk fat, protein and solid not fat on $21 \mathrm{~d}$ of lactation $(P=0.07)$. Sows fed dry feeding type also showed higher milk energy content in milk of 21d lactation $(P=0.05)$. Furthermore, liquid feeding treatment showed high occurrence in feed waste during lactation period $(P<0.01)$.
\end{abstract}

Conclusion: Dry feeding method was more suitable feeding method to lactating sows under high temperature environment like lactating barn.

Keywords: Dry feeding, Lactating sow, Liquid feeding, Piglet, High temperature environment

\section{Background}

Since nutrient utilization of lactating sows was focused on milk production, insufficient nutrient intake caused body composition loss for maintain milk production [13]. Therefore low feed intake during lactation caused severe body weight loss, delayed WEI, reduced conception rate, ovulation rate and fetus survival rate $[1,5,6,22]$. Some research had been demonstrated that liquid feeding group had higher feed intake rather than dry feeding group $[7,8,14]$.
Generally lactating sows were accommodated in high temperature environment for suckling piglets in Korea. For these reasons, liquid feeding system has been introduced to domestic swine farms for improving feed efficiency and feed intake under high temperature environment. However, negative cognition about liquid feeding system has been remained for feed waste decay related with poor management and microbial contamination. Therefore this study was conducted to evaluate the effect of dry feeding and liquid feeding on the productivity and feed intake of lactating sows.

\footnotetext{
* Correspondence: yooykim@snu.ac.kr

School of Agricultural Biotechnology, Seoul National University, Seoul, Korea
} 


\section{Methods}

\section{Animal and housing}

All experimental procedures involving animals were conducted in accordance with the Animal Experimental Guidelines provided by the Seoul National University Institutional Animal Use and Care Committee (SNUIAUCC; SNU-160613-13).

A total of 30 gestating sows (Yorkshire $\times$ Landrace, average parity 4.13) with an initial BW of $218.8 \pm 19.5 \mathrm{~kg}$ were used in a 3 week lactation experiment. Sows were allotted to 1 of 2 treatments in a completely randomized design by their body weight, backfat thickness, parity and litter weight. When day 110 of gestation, sows were moved into individual farrowing crates $\left(2.5 \times 1.8 \mathrm{~m}^{2}\right)$ and housed until weaning. Before 5 days of parturition day, each experimental diet was provided to sows for adaptation with reducing the diet $200 \mathrm{~g} / \mathrm{d}$ until predicted day of parturition. After parturition, they fed the diet increased gradually from $1 \mathrm{~kg} / \mathrm{d}$ by $1 \mathrm{~kg} / \mathrm{d}$ until 5 day postpartum $(5 \mathrm{~kg}$ at 5 day postpartum). After 5 day postpartum, feed and water were provided ad libitum to sows. Lactating sows were provided a feeder and a waterer, separately. Within $24 \mathrm{~h}$ postpartum, Fe-dextran (150ppm) injection, ear notching, needle teeth clipping and tail docking were practiced to all piglets. Piglets were cross-fostered across treatments within 1 day after birth to balance suckling intensity of sows with equalization of litter size, and thus to minimize any impact of initial litter size potentially affecting litter growth. In addition, male piglets were castrated in 3 days postpartum. During lactation period, all lactating sows and their progeny were raised in individual farrowing barn where the indoor temperature was regulated by automatic ventilation system and room temperature was kept automatically at $27-30{ }^{\circ} \mathrm{C}$ by heating lamps.

\section{Experimental design and diet}

Treatment was composed of dry feeding and liquid feeding. Dry feeding treatment was only fed the solid feed. Liquid feeding treatment was fed the liquid-form diet with mixed solid feed and water (1:1). Feeding time was at 08:00, 11:00, 14:00, 17:00, 20:00, 23:00 and once feeding amount was ad libitum until $1 \mathrm{~h}$ after feeding time. In next feeding time, we checked the status of feed in feeder for determining the feed waste or not. Feed was used commercial lactating sows' diet produced by commercial company in Korea. The chemical composition of experimental feed was presented in Table 1.

\section{Measurements}

Body weight and backfat thickness of sows were measured at $24 \mathrm{~h}$ postpartum and 21 day of lactation. Body weight of sows was measured by weight machine (CAS, Korea). An ultra-sound device (Renco lean meter, Renco
Table 1 Chemical composition of experimental feed

\begin{tabular}{ll}
\hline Chemical composition & $\%$ \\
\hline Metabolizable energy, kcal $^{\text {a }}$ & 3265.00 \\
Ether extract $^{\mathrm{b}}, \%$ & 5.76 \\
Crude protein $^{\mathrm{b}}, \%$ & 12.60 \\
Total lysine $^{\mathrm{a}}, \%$ & 1.09 \\
Total methionine $^{\mathrm{a}}, \%$ & 0.25 \\
Crude ash $^{\mathrm{b}}, \%$ & 4.95 \\
Total calcium $^{\mathrm{b}}$, \% & 0.45 \\
Total phosphorus $^{\mathrm{b}}, \%$ & 0.50 \\
\hline
\end{tabular}

a Calculated value

${ }^{\mathrm{b}}$ Analyzed value

Corp., Minneapolis, USA) was used for measuring backfat thickness at $\mathrm{P}_{2}$ position (mean value from both side of the last rib and $65 \mathrm{~mm}$ away from the backbone). The piglet weight was recorded within $24 \mathrm{~h}$ postpartum and at 21 day of lactation and the number of piglets was recorded after cross-fostering and at 21 day of lactation. Litter weight was calculated by summing the individual piglet weights from one sow at after-fostering and 21d of lactation. Weaning to estrus interval was recorded from day of weaning to day of first estrus sign. Feed intake was recorded during experimental period (0-3 week) and feed waste was checked frequently when sows fed the dry-form and liquid-form diet. Feed waste was determined the status of feed in individual feeder, such as sour smell of feed and animal behavior (feed intake rejection). After the feed waste was taken out, feed waste was dried by drying oven and weighted. Colostrum and milk samples were taken from the 5 sows of each treatment at $24 \mathrm{~h}$ postpartum and 21 day lactation, respectively. After injection of oxytocin $0.3 \mathrm{ml}(10 \mathrm{IU} / \mathrm{ml})$ through ear vein, milks were collected from first or second teat of lactating sow. After milk collection in conical tube $(50 \mathrm{ml})$, samples were stored in a freezer $\left(-20{ }^{\circ} \mathrm{C}\right)$ until further analysis. Proximate analysis of colostrum and milk (21d) was conducted using Milkoscan FT 120 (FOSS Electric). The milk production (g), milk dry matter ( $\mathrm{g}$ ) and milk energy (kcal) were calculated from piglet weights and growth rates by equations in Noblet and Etienne [11]. Milk production $(\mathrm{g})=2.50 \times$ piglet $\mathrm{ADG}(\mathrm{g})+80.2 \times$ initial piglet $\mathrm{BW}(\mathrm{kg})+7$, Milk DM $(\mathrm{g})=0.401 \times$ piglet ADG $(\mathrm{g})+12.9 \times$ initial piglet $\mathrm{BW}(\mathrm{kg})+19$, Milk energy $(\mathrm{kcal})=2.54 \times$ piglet ADG $(\mathrm{g})+78.7 \times$ initial piglet BW $(\mathrm{kg})+153$. Also, the energy content of milk at colostrum and $21 \mathrm{~d}$ of lactation was calculated by equation of Perrin [17] through milk composition such as fat, protein, lactose. Milk energy (cal/ $100 \mathrm{gl})=9.11 \mathrm{fat}(\%)+5.86$ protein $(\%)+3.95$ lactose $(\%)$.

\section{Statistical analysis}

The experimental data was analyzed using Student's $t$ test procedure of SAS (SAS Inst., Inc., Cary, NC), and a 
main effect in the statistical model was lactation feeding method. For analyzing sow performance, litter performance and other collected data, individual sow and each litter were considered as an experimental unit. Probability values less than $0.05(P<0.05)$ were considered as significant difference; $P<0.10$ were indicative of a trend; and values equal to or greater than 0.10 were considered as non-significant difference.

\section{Results}

Dry feeding treatment had greater body weight loss than liquid feeding treatment (Table 2, $P=0.04$ ). However, there was no significant difference in backfat thickness and its changes. Daily feed intake had no difference among treatment and weaning to estrus interval (WEI) also was not affected by feeding type.

The number of piglets at after cross-fostering and 21d of lactation had no significant difference among treatment (Table 3). Dry feeding treatment had a tendency to increase litter weight at $21 \mathrm{~d}$ of lactation rather than liquid feeding treatment $(P=0.06)$. Moreover, litter weight gain during lactation period (0-3 week) had greater in sows fed dry feed type $(P=0.04)$. Nevertheless the result of litter weight, piglet weight (3 week) and piglet weight gain (0-3 week) did not show any significant difference.

Milk dry matter, energy content and production amount during lactation period ( $0-3$ week) was not affected by dry feeding or liquid feeding (Table 4). As a result, sows fed dry feeding type showed higher milk energy content in milk of $21 \mathrm{~d}$ lactation $(P=0.05)$.

Milk composition of colostrum had no difference between dry feeding and liquid feeding excluding lactose (Table 5). Sows fed dry feeding method showed higher

Table 2 Effect of dry feeding and liquid feeding on physiological status in lactating sows ${ }^{\text {a }}$

\begin{tabular}{|c|c|c|c|c|}
\hline \multirow[t]{2}{*}{ Criteria } & \multicolumn{2}{|l|}{ Treatment $^{\mathrm{b}}$} & \multirow[t]{2}{*}{ SEM $^{c}$} & \multirow[t]{2}{*}{$P$-value } \\
\hline & Dry feeding & Liquid feeding & & \\
\hline \multicolumn{5}{|l|}{ Body weight, kg } \\
\hline $24 \mathrm{~h}$ postpartum & 224.03 & 213.73 & 3.561 & 0.15 \\
\hline Day 21 of lactation & 215.73 & 217.07 & 3.016 & 0.83 \\
\hline BW changes $(0-21 d)$ & -8.30 & 3.34 & 2.816 & 0.04 \\
\hline \multicolumn{5}{|l|}{ Backfat thickness, mm } \\
\hline $24 \mathrm{~h}$ postpartum & 18.9 & 20.6 & 1.07 & 0.44 \\
\hline Day 21 of lactation & 18.2 & 20.1 & 0.90 & 0.29 \\
\hline BF changes $(0-21 d)$ & -0.7 & -0.5 & 0.68 & 0.87 \\
\hline Daily feed intake, kg/d & 6.16 & 5.87 & 0.183 & 0.43 \\
\hline WEI ${ }^{d}, d$ & 4.36 & 4.50 & 0.128 & 0.28 \\
\hline
\end{tabular}

${ }^{\mathrm{a}} \mathrm{A}$ total of 30 lactating sows (Yorkshire $\mathrm{x}$ Landrace) with an initial BW of $218.8 \pm 19.5 \mathrm{~kg}$ were used in a 3 week trial

${ }^{b}$ Dry feeding: solid feed only, liquid feeding: solid feed 50\%: water 50\% mixed

c Standard error of mean

${ }^{d}$ WEl: weaning to estrus interval
Table 3 Effect of dry feeding and liquid feeding on litter performance in lactating sows

\begin{tabular}{|c|c|c|c|c|}
\hline \multirow[t]{2}{*}{ Criteria } & \multicolumn{2}{|l|}{ Treatment } & \multirow[t]{2}{*}{ SEM $^{a}$} & \multirow[t]{2}{*}{$P$-value } \\
\hline & Dry feeding & Liquid feeding & & \\
\hline \multicolumn{5}{|l|}{ No. of piglets } \\
\hline After cross-fostering & 13.00 & 12.93 & 0.242 & 0.89 \\
\hline Day 21 of lactation & 11.73 & 11.40 & 0.196 & 0.40 \\
\hline \multicolumn{5}{|l|}{ Litter weight, kg } \\
\hline After cross-fostering & 19.41 & 19.29 & 0.571 & 0.92 \\
\hline Day 21 of lactation & 64.63 & 57.16 & 1.985 & 0.06 \\
\hline Weight gain $(0-21 d)$ & 45.22 & 37.87 & 1.781 & 0.04 \\
\hline \multicolumn{5}{|l|}{ Piglet weight, kg } \\
\hline After cross-fostering & 1.50 & 1.49 & 0.040 & 0.84 \\
\hline Day 21 of lactation & 5.51 & 5.05 & 0.161 & 0.16 \\
\hline Weight gain (0-21d) & 4.00 & 3.56 & 0.153 & 0.15 \\
\hline
\end{tabular}

${ }^{\mathrm{a}}$ Standard error of mean

lactose content of colostrum than sows fed liquid feeding method $(P=0.04)$. In otherwise, sows fed dry feeding method made milk containing high content of casein and total solid rather than sows fed liquid feeding method $(P=0.04)$. In addition, dry feeding treatment had tendency to higher content of milk fat, protein and solid not fat on $21 \mathrm{~d}$ of lactation $(P=0.07)$.

In current study, liquid feeding treatment showed high occurrence in feed waste during lactation period (Table $6, P<0.01)$. Furthermore, feed waste resulted from liquid feeding treatment caused severe economic losses (Table $6, P<0.01)$.

\section{Discussion}

The result of body weight loss during lactation (0 to 3 week) was in accordance with Peng et al. [15]. They

Table 4 Effect of dry feeding and liquid feeding on milk production in lactating sows

\begin{tabular}{|c|c|c|c|c|}
\hline \multirow[t]{2}{*}{ Criteria } & \multicolumn{2}{|l|}{ Treatment } & \multirow[t]{2}{*}{ SEM $^{\mathrm{a}}$} & \multirow[t]{2}{*}{$P$-value } \\
\hline & Dry feeding & Liquid feeding & & \\
\hline \multicolumn{5}{|l|}{ Milk production ${ }^{b}$} \\
\hline Milk dry matter, g & 114.81 & 106.25 & 3.002 & 0.16 \\
\hline Milk production, g & 603.98 & 550.60 & 18.715 & 0.16 \\
\hline \multicolumn{5}{|l|}{ Milk energy content } \\
\hline Milk $(0-21 \mathrm{~d})^{\mathrm{b}}, \mathrm{kcal} / \mathrm{g}$ & 755.35 & 701.15 & 18.987 & 0.16 \\
\hline Colostrum $^{c}, \mathrm{cal} / 100 \mathrm{~g}$ & 137.77 & 151.94 & 8.009 & 0.41 \\
\hline Milk $(21 \mathrm{~d})^{c}, \mathrm{cal} / 100 \mathrm{~g}$ & 121.02 & 104.74 & 4.303 & 0.05 \\
\hline \multicolumn{5}{|c|}{$\begin{array}{l}\text { a Standard error of mean } \\
\text { b Equations from Noblet and Etienne [11] } \\
\text { - Milk production }(\mathrm{g})=2.50 \times \text { piglet ADG }(\mathrm{g})+80.2 \times \text { initial piglet BW }(\mathrm{kg})+7 \\
\text { - Milk DM }(\mathrm{g})=0.401 \times \text { piglet ADG }(\mathrm{g})+12.9 \times \text { initial piglet BW }(\mathrm{kg})+19 \\
\text { - Milk energy }(\mathrm{kcal})=2.54 \times \text { piglet ADG }(\mathrm{g})+78.7 \times \text { initial piglet BW }(\mathrm{kg})+153 \\
{ }^{\mathrm{C}} \text { Equations from Perrin }[17] \\
\text { - Milk energy }(\mathrm{cal} / 100 \mathrm{gl})=9.11 \mathrm{fat}(\%)+5.86 \text { protein }(\%)+3.95 \text { lactose }(\%)\end{array}$} \\
\hline
\end{tabular}


Table 5 Effect of dry feeding and liquid feeding on milk composition of colostrum and milk at 21d lactation

\begin{tabular}{|c|c|c|c|c|}
\hline \multirow[t]{2}{*}{ Criteria } & \multicolumn{2}{|l|}{ Treatment } & \multirow[t]{2}{*}{ SEM $^{a}$} & \multirow[t]{2}{*}{$P$-value } \\
\hline & Dry feeding & Liquid feeding & & \\
\hline \multicolumn{5}{|l|}{ Milk composition } \\
\hline \multicolumn{5}{|l|}{ Casein, \% } \\
\hline $24 \mathrm{~h}$ postpartum & 6.03 & 6.52 & 0.256 & 0.37 \\
\hline Day 21 of lactation & 4.76 & 4.18 & 0.153 & 0.04 \\
\hline \multicolumn{5}{|l|}{ Fat, \% } \\
\hline $24 \mathrm{~h}$ postpartum & 8.29 & 9.57 & 0.845 & 0.48 \\
\hline Day 21 of lactation & 7.20 & 5.81 & 0.384 & 0.07 \\
\hline \multicolumn{5}{|l|}{ Protein, \% } \\
\hline $24 \mathrm{~h}$ postpartum & 7.51 & 8.36 & 0.350 & 0.25 \\
\hline Day 21 of lactation & 5.34 & 4.66 & 0.194 & 0.07 \\
\hline \multicolumn{5}{|l|}{ Lactose, \% } \\
\hline $24 \mathrm{~h}$ postpartum & 4.61 & 4.01 & 0.140 & 0.04 \\
\hline Day 21 of lactation & 6.11 & 6.21 & 0.042 & 0.28 \\
\hline \multicolumn{5}{|l|}{ Total solid, \% } \\
\hline $24 \mathrm{~h}$ postpartum & 22.50 & 24.36 & 0.997 & 0.38 \\
\hline Day 21 of lactation & 20.09 & 18.05 & 0.534 & 0.04 \\
\hline \multicolumn{5}{|l|}{ Solid not fat, \% } \\
\hline 24 h postpartum & 12.52 & 12.72 & 0.333 & 0.78 \\
\hline Day 21 of lactation & 11.50 & 10.94 & 0.158 & 0.07 \\
\hline \multicolumn{5}{|l|}{ Free fatty acid, \% } \\
\hline $24 \mathrm{~h}$ postpartum & 3.02 & 3.09 & 0.143 & 0.81 \\
\hline Day 21 of lactation & 8.98 & 8.72 & 0.646 & 0.85 \\
\hline
\end{tabular}

a Standard error of mean

presented that sows fed with wet feeding had greater feed intake and less body weight loss rather than those of dry feeding during lactation. In addition, O'Grady and Lynch [14], Koketsu [7], and Lynch [8] demonstrated that lactating sows had higher feed intake 12,11 , and $7 \%$, respectively when the feed was wet or watery. However, the result of body weight loss in drying feeding treatment was caused from not daily feed intake but growth of suckling piglets. Because lactating sows usually meet their nutrient requirement for milk production primarily from feed intake but also from body protein and fat tissue storage [9]. Moreover, milk production of lactating sow is dependent

Table 6 Effect of dry feeding and liquid feeding on economic loss in swine farm

\begin{tabular}{|c|c|c|c|c|}
\hline \multirow[t]{2}{*}{ Criteria } & \multicolumn{2}{|l|}{ Treatment } & \multirow[t]{2}{*}{ SEM $^{a}$} & \multirow[t]{2}{*}{$P$-value } \\
\hline & Dry feeding & Liquid feeding & & \\
\hline Daily feed intake, kg/d & 6.16 & 5.87 & 0.183 & 0.43 \\
\hline Total feed wastage, kg & 0.75 & 7.97 & 0.985 & $<0.01$ \\
\hline Feed waste cost ${ }^{\mathrm{b}}$, won & 376 & 3986 & 492.6 & $<0.01$ \\
\hline
\end{tabular}

a Standard error of mean

${ }^{b}$ Feed cost: 500 won/kg upon the litter $[2,19]$. Thus high litter weight gain during lactation demonstrated high milk production of lactating sows [11]. When energy intake is often not sufficient to support milk production, and sows will mobilize body lipid and protein stores to support lactation [10, 12]. Therefore increasing milk production or litter weight gain caused to greater body weight loss of lactating sows under same dietary feed or nutrient intake [10].

The occurrence of feed waste in liquid feeding treatment caused to different result of average daily feed intake during lactation compared with previous studies $[7,8,14,15]$. In the research of Peng et al. [15], wet feeding treatment was fed self-automatically (wet/dry system with nipple drinker inside the feeder). On the contrary to this, current study prepared the liquid feed just before the feeding and fed some amount of liquid feed continuously until end of feed intake. For this experimental environment, feed waste of liquid feeding treatment occurred inevitably same with Peng et al. [15]. Under high temperature environment like lactating barn $\left(27-30{ }^{\circ} \mathrm{C}\right)$, microbial contaminated wet feed waste or liquid type of feed waste which often occurred because of highly microbial activity [4]. It led to rejection of feed intake in lactating sows and negative effects on milk production and milk quality. The nutritional importance of mammary amino acid uptake did not match the amino acid profile in the milk [3] and the amino acid requirements during lactation would be higher than current estimates. For instance, Richert et al. [18] demonstrated a response in litter weight gain and dietary valine level and Pettigrew [16] reported that lysine requirement increased linearly as daily litter growth rate increased during lactation. Unfortunately, microbial contamination within liquid feed wastage broke down the amino acids balance of dietary feed [20] and reduced dietary energy content of feed [21]. It led to negative influence on milk production and milk quality. Since sows were not provided fresh liquid feed and sanitary feeder environment was always with same amount of daily feed intake, sows fed dry feeding had high milk component(casein, fat protein, total solid, solid not fat) and high energy content at milk of 21d lactation.

\section{Conclusion}

Lactating sows fed dry feeding had greater body weight loss compared with liquid feeding group. It led to high content and quality of milk production and good litter performance during lactation period. Considering the feed waste under high temperature environment and economic loss, dry feeding method was more suitable feeding method to lactating sows under high temperature environment like lactating barn. 


\section{Abbreviations}

ADG: Average daily gain; BW: Body weight; CP: Crude protein; DM: Dry matter; EE: Ether extract; ME: Metabolizable energy; NRC: National Research Council; WEl: Weaning to estrus interval

\section{Acknowledgement}

The study was supported by the Rural Development Administration (PJ011617012016) in Korea.

\section{Availability of data and materials}

Authors approved the data and materials availability.

\section{Authors' contributions}

JSH was mainly carried out this study and drafted the manuscript. SSJ, SWJ and LHF participated in the feeding and experiment. YYK conceived of the study, and participated in its design and coordination and helped to draft the manuscript. All authors read and approved the final manuscript.

\section{Competing interests}

The authors declare that they have no competing interest.

\section{Consent for publication}

Not applicable.

\section{Ethics approval and consent to participate}

All experimental procedures involving animals were conducted in accordance with the Animal Experimental Guidelines provided by the Seoul National University Institutional Animal Use and Care Committee (SNUIAUCC; SNU-160613-13).

Received: 9 May 2016 Accepted: 8 October 2016

Published online: 21 October 2016

\section{References}

1. Baidoo SK, Aherne FX, Kirkwood RN, Foxcroft GR. Effect of feed intake during lactation and after weaning on sow reproductive performance. Can J Anim Sci. 1992;72:911-7.

2. Boyd R, Kensinger RS, Harrell RJ, Bauman DE. Nutrient uptake and endocrine regulation of milk synthesis by mammary tissue of lactating sows. J Anim Sci. 1995;73:36-56

3. Dourmad JY, Noblet J, Etienne M. Effect of body protein and lysine supply on performance, nitrogen balance, and body composition changes of sows during lactation. J Anim Sci. 1998;76:542-50.

4. Han YK, Thacker PA, Yang JS. Effects of the duration of liquid feeding on performance and nutrient digestibility in weaned pigs. Asian-Aust J Anim Sci. 2006:19:396-401.

5. Kirkwood RN, Baidoo SK, Aherne FX, Sather AP. The influence of feeding level during lactation on the occurrence and endocrinology of the post weaning estrus in sows. Can J Anim Sci. 1987a;67:405-415.

6. Kirkwood RN, Lythgoe ES, Aherne FX. Effect of lactation feed intake and gonadotrophin-releasing hormone on the reproductive performance of sows. Can J Anim Sci. 1987b;67: 715-719.

7. Koketsu Y. Influence of feed intake and other factors on the lactational and postweaning reproductive performance of sows. PhD Dissertation. St. Paul: University of Minnesota; 1994.

8. Lynch PB. Factors affecting voluntary feed intake in the sow during the lactation period. PhD Dissertation. Dublin: National University of Ireland; 2001.

9. Mullan BP, Williams $\mathbb{H}$. The chemical composition of sows during their first lactation. Anim Prod. 1990:51:375-87.

10. Noblet J, Etienne M. Metabolic utilization of energy and maintenance requirements in lactating sows. J Anim Sci. 1987:64:774-81.

11. Noblet J, Etienne M. Estimation of sow milk nutrient output. J Anim Sci. 1989:67:3352-9.

12. Noblet J, Dourmad JY, Etienne M. Energy utilization in pregnant and lactating sows: modeling of energy requirements. J Anim Sci. 1990;68:562-72

13. NRC. Predicting Feed Intake of Food Producing Animals. Washington: National Academy Press; 1987.

14 O'Grady JF, Lynch PB. Voluntary feed intake by lactating sows: influence of system of feeding and nutrient density of the diet. Irish J Agri Res. 1978;17:1-5.
15 Peng JJ, Somes SA, Rozeboom DW. Effect of system of feeding and watering on performance of lactating sows. J Anim Sci. 2007:85:853-60.

16 Pettigrew JE. Amino acid nutrition of gestating and lactating sows. BioKyowa Tech Rev. 1993:5:2-18.

17 Perrin DR. The composition of sow's milk during the course of lactation. J Dairy Res. 1954;21:55-62.

18 Richert BT, Tokach MD, Goodband RA, Nelssen JL, Pettigrew JE, Walker RA Johnston $L$ J. Valine requirement of the high-producing lactating sow. J Anim Sci. 1996;74:1307-13.

19 Sauber TE, Stahly TS, Ewan RC, Williams NH. Maximum lactational capacity of sows with high and low genetic capacity for lean tissue growth. J Anim Sci. 1994;72:364

20 Scholten RHJ, Schraum JW, van der Peet-Schwering CMC, den Hartog LA Vesseur PC, van Leeuwen P, Verstegen MWA. The dose-response effect of fermented liquid wheat on growth performance and gastrointestinal health of weaned piglets. In: Lindberg JE, editor. 8th Proc. Symp. Dig. Physiol. in Pigs, Uppsala, Sweden. 2000;246-266.

21 Smith P. Comparison of dry, wet and soaked meal for fattening bacon pigs. Experimental Husbandry. 1976;30:87-94.

22 Zak LJ, Cosgrove JR, Aherne FX, Foxcroft GR. Pattern of feed intake and associated metabolic and endocrine changes differentially affect postweaning fertility in primiparous lactating sows. J Anim Sci. 1997:75:208-16.

\section{Submit your next manuscript to BioMed Central and we will help you at every step:}

- We accept pre-submission inquiries

- Our selector tool helps you to find the most relevant journal

- We provide round the clock customer support

- Convenient online submission

- Thorough peer review

- Inclusion in PubMed and all major indexing services

- Maximum visibility for your research

Submit your manuscript at www.biomedcentral.com/submit 